Article

\title{
A Fermented Milk Matrix Containing Postbiotics Supports Th1- and Th17-Type Immunity In Vitro and Modulates the Influenza-Specific Vaccination Response In Vivo in Association with Altered Serum Galectin Ratios
}

\author{
Veronica Ayechu-Muruzabal ${ }^{1}$ (D), Ling Xiao ${ }^{1}$, Tjalling Wehkamp ${ }^{2}$, Ingrid van Ark ${ }^{1}$, Elisabeth J. Hoogendoorn ${ }^{1}$, \\ Thea Leusink-Muis ${ }^{1}(\mathbb{D})$, Gert Folkerts ${ }^{1} \mathbb{D}$, Johan Garssen ${ }^{1,2} \mathbb{D}$, Linette E. M. Willemsen ${ }^{1}$ \\ and Belinda van't Land $2,3, *$ (D)
}

1 Division of Pharmacology, Utrecht Institute for Pharmaceutical Sciences, Utrecht University, 3584 CG Utrecht, The Netherlands; v.ayechumuruzabal@uu.nl (V.A.-M.);

Ling.Xiao@joslin.harvard.edu (L.X.); I.vanArk@uu.nl (I.v.A.); E.J.Hoogendoorn@students.uu.nl (E.J.H.); A.Leusink@uu.nl (T.L.-M.); G.Folkerts@uu.nl (G.F.); Johan.Garssen@danone.com (J.G.); L.E.M.Willemsen@uu.nl (L.E.M.W.)

2 Danone Nutricia Research, 3584 CT Utrecht, The Netherlands; Tjalling.Wehkamp@danone.com

check for updates

Citation: Ayechu-Muruzabal, V.; Xiao, L.; Wehkamp, T.; van Ark, I.; Hoogendoorn, E.J.; Leusink-Muis, T.; Folkerts, G.; Garssen, J.; Willemsen, L.E.M.; van't Land, B. A Fermented Milk Matrix Containing Postbiotics Supports Th1- and Th17-Type Immunity In Vitro and Modulates the Influenza-Specific Vaccination Response In Vivo in Association with Altered Serum Galectin Ratios. Vaccines 2021, 9, 254. https:// doi.org/10.3390/vaccines9030254

Academic Editor: Federico Iovino

Received: 3 February 2021

Accepted: 11 March 2021

Published: 13 March 2021

Publisher's Note: MDPI stays neutral with regard to jurisdictional claims in published maps and institutional affiliations.

Copyright: (c) 2021 by the authors. Licensee MDPI, Basel, Switzerland. This article is an open access article distributed under the terms and conditions of the Creative Commons Attribution (CC BY) license (https:/ / creativecommons.org/licenses/by/ $4.0 /)$.
3 Center for Translational Immunology, The Wilhelmina Children's Hospital, University Medical Center Utrecht, 3584 EA Utrecht, The Netherlands

* Correspondence: b.vantland@umcutrecht.nl; Tel.: +31-6-31904752

\begin{abstract}
During a specific milk fermentation process with Bifidobacterium breve C50 and Streptococcus thermophilus 065 (Lactofidus ${ }^{\mathrm{TM}}$ ), postbiotics with possible immunomodulatory properties are produced. We investigated the effects of this fermentation product (FP) in vitro using a model that allows crosstalk between intestinal epithelial (IEC) and immune cells. IECs were exposed to FP and $\alpha \mathrm{CD} 3 / \mathrm{CD} 28$-activated peripheral blood mononuclear cells after which the mediator secretion was measured. Additionally, using a murine influenza vaccination model, immune development was assessed. Mice were fed an AIN93G diet containing FP or lactose as control. Vaccine-specific immunity was measured as delayed-type hypersensitivity (DTH) and correlated to intestinal and systemic immunomodulation levels. In vitro, exposure to FP enhanced IFN $\gamma$, TNF $\alpha$ and IL-17A concentrations. Moreover, IEC-derived galectin- 3 /galectin- 9 and galectin- 4 /galectin- 9 ratios were increased. In vivo, dietary intervention with FP increased vaccine-specific DTH responses as compared to the lactose-receiving group. Although no effects on humoral immunity and vaccine-specific T-cell responses were detected, an enhanced systemic serum galectin-3/galectin- 9 and galectin- 4 /galectin- 9 ratio correlated with a shift in ROR $\gamma$ (Th17) mRNA expression over regulatory TGF $\beta 1$ in the ileum. This was also positively correlated with the increased DTH response. These results indicate that FP can enhance epithelial galectin- 3 and -4 over galectin- 9 release, and boost adaptive immunity by promoting Th1- and Th17-type cytokines under inflammatory conditions in vitro. Similar variations in galectin and immune balance were observed in the vaccination model, where FP improved the influenza-specific DTH response.
\end{abstract}

Keywords: postbiotics; vaccination; influenza; galectins; fermentation; adaptive immunity

\section{Introduction}

The development of the mucosal immune system constitutes a crucial stage in early life and its development represents a decisive period for the establishment of a balanced mucosal immune and systemic immune function [1,2]. Diet plays a pivotal role by providing all the necessary nutrients for growth and development of a healthy gut and supporting the establishment of a balanced microbiome and a proper maturation of the immune system. Breastfeeding is considered the gold standard for infant nutrition, and as such, the 
World Health Organization recommends exclusive breastfeeding during at least the first six months of life, which can be extended up to two years or beyond next to complementary food introduction [3].

Current research is focused on developing alternative nutritional interventions for those infants that are unable to receive enough breastmilk. Although human milk is always the preferred option for infant nutrition, fermented milk-based infant formulas are being developed [4] and studied for their ability to modulate the immune function [5]. Fermented milk-based formulas are obtained by fermentation of a milk matrix with lactic acid-producing bacteria, followed by heat-inactivation of viable bacteria. This fermentation process results in the formation of bioactive components known as postbiotics. Postbiotics are defined as bioactive compounds produced by food-grade microorganisms in a fermentation process (including microbes, cell constituents and metabolites) that in adequate amounts promote health and/or well-being of the host [4,6-8]. Postbiotics refer to soluble factors such as enzymes, proteins, polysaccharides, short-chain fatty acids and peptidoglycans, known to promote diverse local as well as systemic effects, among which immunomodulation and anti-inflammation stand out [7].

Specific fermented infant formulas containing postbiotics are commercially available and their possible beneficial effects have been systematically reviewed [9]. The most extensively studied postbiotics are derived from Lactobacillus, Streptococcus and Bifidobacterium strains due to their use as probiotics [6] as well as in regard to the beneficial effects shown in cell-mediated immunity and inflammation [10]. One of the most studied fermented formula is obtained through a unique fermentation process of a milk matrix (Lactofidus ${ }^{\mathrm{TM}}$ ) using two bacterial strains namely Bifidobacterium breve C50 and Streptococcus thermophilus 065 , known to generate bioactive components such as $3^{\prime}$ galactosyllactose; a non-digestible oligosaccharide naturally occurring in human milk [11]. Several clinical trials have described improved gut and immune parameters upon dietary intervention with infant formula fermented by B. breve C50 and S. thermophilus 065, summarized by Salminen et al. [4]. Those clinical trials showed that healthy infants receiving infant formula supplemented with fermentation products from B. breve and S. thermophilus, had lower severity of acute diarrhea episodes [12], enhanced thymus size [13], lowered fecal calprotectin and increased secretory IgA [14]. Furthermore, systemic effects such as an increased anti-poliovirus IgA response was also seen in infants fed an infant formula supplemented with fermentation products [15]. Additionally, in infants at high risk of atopy who were fed a fermented infant milk formula, fewer cases of positive skin-prick test to cow's milk were observed [16]. In vitro fermentation products (FP) derived from a fermentation of a milk matrix with $B$. breve $\mathrm{C} 50$ and $\mathrm{S}$. thermophilus 065 were shown to promote immunomodulatory effects in dendritic cells by increasing IL-10 release [17] as well as stimulating a Th1 immune response in mice [18].

In an in vivo influenza vaccination model, specific non-digestible oligosaccharides effectively improved vaccine-specific immune responses by promoting Th1-type immunity [19-23]. Furthermore, in vitro and in vivo combined exposure to non-digestible oligosaccharides and specific bacteria or bacterial fragments (bacterial CpG DNA) has previously been shown to drive regulatory-type Th1 responses, among others, via instruction of epithelial-derived galectin release [24-27].

Regarding the immunoregulatory capacities of milk-based fermented formula shown in vitro and in vivo, we hypothesize that FP could be able to improve the response to an influenza vaccine in a murine vaccination model by exerting an effect in the gut. Hence, the aim of this study was to investigate the possible immunomodulatory effects of a fermented milk matrix containing possible bioactive fermentation products (FP) produced following the Lactofidus ${ }^{\mathrm{TM}}$ fermentation process, and to study its effect in the influenza vaccination model. An established in vitro co-culture model combining human intestinal epithelial as well as immune cells $[24,25,28]$ was used to study the effect of FP on the epithelial cell and immune cells crosstalk. Additionally, a murine influenza vaccination model was used to study the effects of a dietary intervention with FP on vaccination responses. FP was found 
to modulate the galectin-3 and galectin- 4 over galectin- 9 balance systemically, which correlated with an increased influenza-specific delayed-type hypersensitivity (DTH) response.

\section{Materials and Methods}

2.1. In Vitro IEC/PBMC Co-Culture Model

\subsubsection{Intestinal Epithelial Cell Culture}

Human intestinal epithelial cells (IEC), HT-29 cell line (ATCC, HTB-38, Manassas, VA, USA), were cultured in $75 \mathrm{~cm}^{2}$ cell culture flasks (Greiner Bio-One, Alphen aan den Rijn, The Netherlands) using Mc Coy 5A medium (Gibco, Invitrogen, Carlsbad, CA, USA) supplemented with $10 \%$ heat-inactivated fetal-calf serum (FCS), penicillin $(100 \mathrm{U} / \mathrm{mL})$ and streptomycin $(100 \mu \mathrm{g} / \mathrm{mL})$ (Sigma-Aldrich, St. Louis, MO, USA). HT-29 cells were kept in an incubator at $37^{\circ} \mathrm{C}$ and $5 \% \mathrm{CO}_{2}$. Cells were passaged once a week and medium was refreshed every $2-3$ days.

\subsubsection{Peripheral Blood Mononuclear Cells Isolation}

Buffy coats from healthy donor (Sanquin, Amsterdam, The Netherlands) were used to isolate human peripheral blood mononuclear cells (PBMC) by density gradient centrifugation $(100 \times \mathrm{g}$, $13 \mathrm{~min})$. After centrifugation, the pellet was washed with PBS supplemented with $2 \%$ FCS. The remaining erythrocytes were lysed using red blood cell lysis buffer $(4.14 \mathrm{~g}$ $\mathrm{NH} 4 \mathrm{Cl}, 0.5 \mathrm{~g} \mathrm{KHCO} 3,18.6 \mathrm{mg}$ Na2EDTA in $500 \mathrm{~mL}$ demi water, sterile filtered, $\mathrm{pH}=7.4$ ) for $5 \mathrm{~min}$ on ice. The isolated PBMC fraction was resuspended in RPMI 1640 supplemented with $2.5 \%$ FCS, penicillin $(100 \mathrm{U} / \mathrm{mL})$ and streptomycin $(100 \mu \mathrm{g} / \mathrm{mL})$.

\subsubsection{IEC/PBMC Co-Culture Model}

One week prior to the experiment, HT-29 cells were diluted five to eight times based on cell surface area and seeded in transwell inserts (12-well, $0.4 \mu \mathrm{m}$ polyester membrane, Costar Corning Incorporated, NY, USA). When HT-29 reached confluency, they were apically exposed to $0.25-0.5 \% \mathrm{FP}(w / v)$. In the basolateral compartment, $2 \times 10^{6}$ cells $/ \mathrm{mL}$ of $\alpha$ CD3/CD28-activated PBMC (clone CLB-T3/2 and clone CLB-CD28 respectively, both 1:10,000, Sanquin, The Netherlands) were added. After $24 \mathrm{~h}$ of incubation $\left(37^{\circ} \mathrm{C}, 5 \% \mathrm{CO}_{2}\right)$, the basolateral supernatant was collected and stored at $-20{ }^{\circ} \mathrm{C}$ for cytokine measurements.

\subsubsection{Enzyme-Linked Immunosorbent Assay (ELISA)}

The cytokine secretions were analyzed in the basolateral supernatant from IEC/PBMC co-cultures. Commercially available kits were used to determine IFN $\gamma, \mathrm{TNF} \alpha, \mathrm{IL}-17 \mathrm{~A}$, IL13, TGF $\beta 1$ (all from Thermo Fisher scientific, Waltham MA, USA), IL-10 (U-Cytech, Utrecht, The Netherlands) and galectin-3 (R\&D systems, Minneapolis, MN., USA) according to the manufacturer's protocol. Human galectin- 4 and -9 were measured using antibody pairs. In short, high-binding Costar 9018 plates were incubated overnight with $0.75 \mu \mathrm{g} / \mathrm{mL}$ human galectin-4 or -9 affinity purified polyclonal antibody. Non-specific binding was blocked with $1 \%$ bovine serum albumin (BSA) in PBS for one hour, after which samples were added and incubated for $2 \mathrm{~h}$ at room temperature. After washing, biotinylated galectin- 4 or -9 affinity purified polyclonal antibody $(0.75 \mu \mathrm{g} / \mathrm{mL})$ was incubated for $1 \mathrm{~h}$. Then, plates were washed and streptavidin-HRP was incubated for $1 \mathrm{~h}$. After washing, tetramethylbenzidine was used as a substrate to develop the reaction (TMB, Thermo Fisher scientific, Waltham, $\mathrm{MA}, \mathrm{USA}$ ), which was stopped with $1 \mathrm{M} \mathrm{H}_{2} \mathrm{SO}_{4}$. Optical density was measured at $450 \mathrm{~nm}$.

\subsection{In Vivo Influenza Vaccination Model \\ 2.2.1. Animals}

Six-week-old C57Bl/6JOlaHsd female mice were purchased from Envigo (Horst, The Netherlands) and housed under conventional conditions with a light/dark cycle of $12 \mathrm{~h} / 12 \mathrm{~h}$ (lights on from $7.00 \mathrm{am}-7.00 \mathrm{pm}$ ) at controlled relative humidity (relative humidity of $50-55 \%)$ and temperature $\left(21 \pm 2{ }^{\circ} \mathrm{C}\right)$ with access to food and water ad libitum, in the animal facility of Utrecht University. Upon arrival, mice were randomly grouped as 
three mice per cage in filter-topped makrolon cages $(22 \mathrm{~cm} \times 16 \mathrm{~cm} \times 14 \mathrm{~cm}$, floor area $350 \mathrm{~cm}^{2}$, Tecnilab BMI, Someren, The Netherlands) with wood-chip bedding (Tecnilab BMI, Someren, The Netherlands); tissues and a plastic shelter were available as cage enrichment at the animal facility. The animals received standard diets for one week until the start of the experiments. The C57Bl/6JOlaHsd female mice were previously used to establish this influenza vaccination model and further studies are also available [19-23,29].

This study was conducted in accordance with institutional guidelines for the care and use of laboratory animals established by the Animal Ethics Committee of Utrecht University, and all animal procedures were approved under the Ethical license of the national competent authority, securing full compliance the European Directive for the use of animals for scientific purposes.

\subsubsection{Vaccination Protocol and Dietary Intervention}

One week after acclimatization, mice were fed AIN93G diet or the AIN93G diet containing FP or lactose (SNIFF Spezialdiäten GmbH, Soest, Germany) until the end of the experiment by a researcher blinded to the experimental treatments. AIN93G diets were mixed with $0.5 \%$ or $2.5 \%(w / w)$ FP. As a control for the amount of lactose present in the fermented milk matrix, the lactose diets were mixed with $0.25 \%$ and $1.25 \%(w / w)$, respectively. The percentages of FP and lactose were exchanged against an equal amount $(w / w)$ of total carbohydrates present in the control diet.

On days 0 and 21, the mice received a subcutaneous vaccination under isoflurane anesthesia using Influvac season 2015/2016 (Abbot Biologicals B.V., Weesp, The Netherlands). The mice ( $n=9$ per experimental group) received a total volume of $100 \mu \mathrm{L}$ containing $90 \mu \mathrm{g} / \mathrm{mL}$ hemagglutinin from three strains of the influenza virus. A negative control group, referred as sham $(n=3)$, received injections with $100 \mu \mathrm{L}$ PBS. Delayed-type hypersensitivity reactions were induced 9 days after booster vaccination by intradermal injection of $20 \mu \mathrm{L}$ Influvac into the ear pinnae of the right ear. As basal line, $20 \mu \mathrm{L}$ PBS was injected in the left ear pinnae. Ear thickness was measured in duplicate before intradermal challenge and $24 \mathrm{~h}$ thereafter using a digital micrometer (Mitutoyo, Veenendaal, The Netherlands). The antigen-specific delayed-type hypersensitivity (DTH) responses were calculated using the following formula: DTH = Right ear thickness (@24 h-@0 h)-Left ear thickness (@24 h-@0 h). After measuring the ear thickness, mice were anesthetized and sacrificed. Then, the ears were punctured and the weight of the ear puncture was measured.

\subsubsection{Vaccine-Specific Immunoglobulins and Galectins in Serum}

At the end of the experiment, mice were anesthetized and blood was collected by retro-orbital bleeding of the eye. Blood samples were centrifuged (14,000 rpm, $10 \mathrm{~min})$ and serum was stored at $-80^{\circ} \mathrm{C}$ until analysis of vaccine-specific antibodies by means of ELISA. Vaccine-specific antibody titers were measured as described previously [19]. Briefly, 96-well high-binding plates (Costar Corning Incorporated, NY, USA) were coated with 1:100 diluted Influvac in PBS. As blocking reagent, 2\% BSA in PBS was used. Serial dilutions of pooled serum containing vaccine-specific antibodies was done and used for standard curve calculations. Biotinylated anti-IgG1 and anti-IgG2a antibodies (Becton Dickinson, Heerhugowaard, The Netherlands) were diluted 1:100 and incubated for $1 \mathrm{~h}$, after which streptavidin-HRP (Sanquin, Amsterdam, The Netherlands) was added. Optical density was measured at $490 \mathrm{~nm}$ with a microplate reader (Bio-Rad, Veenendaal, The Netherlands). Mouse serum galectin- 4 and -9 (both from R\&D systems) were measured by means of ELISA according to the protocol described in Section 2.1.4. for human galectin-4 and -9 . Purified mouse anti-goat antibodies $(0.2 \mathrm{mg} / \mathrm{mL}$ for galectin- 4 and -9$)$, recombinant mouse cytokines and biotinylated goat anti-mouse antibodies $(0.2 \mathrm{mg} / \mathrm{mL}$ for galectin- 4 and -9) were purchased from R\&D systems. Non-specific binding was blocked using PBS supplemented with 5\% goat serum (Dako, Heverlee, Belgium). Mouse galectin-3 concentrations were measured according to manufacturer's protocol (R\&D systems). 


\subsubsection{Cell Isolation from Tissues}

Lymphocytes were isolated from the spleens and mesenteric lymph-nodes (MLN) of mice sacrificed after the ear thickness measure, $24 \mathrm{~h}$ after challenge. Single-cell splenocyte suspensions were obtained by crushing the spleen through a $70 \mu \mathrm{m}$ nylon cell strainer using a syringe. The splenocyte cell suspensions were incubated with a lysis buffer $(8.3 \mathrm{~g} \mathrm{NH} 4 \mathrm{Cl}$, $1 \mathrm{~g} \mathrm{KHCO} 3$ and $37.2 \mathrm{mg}$ EDTA dissolved in $1 \mathrm{~L}$ demi water, filter-sterilized) for $4 \mathrm{~min}$ on ice to remove the red blood cells. Cell suspensions were resuspended in RPMI 1640 medium (Lonza, Basel, Switzerland) supplemented with 10\% heat-inactivated FCS, $100 \mathrm{U} / \mathrm{mL}$ penicillin, $100 \mu \mathrm{g} / \mathrm{mL}$ streptomycin and $20 \mu \mathrm{M} \beta$-mercapto-ethanol (Thermo Fisher).

\subsubsection{Flow Cytometry of Immune Cells}

Spleen and MLN single cell suspensions $\left(0.5-1 \times 10^{6}\right.$ cells/well) were incubated with anti-mouse CD16/CD32 (Mouse BD Fc Block, BD Biosciences, San Jose, CA, USA) in PBS supplemented with $1 \%$ BSA and $5 \%$ FCS for 15 min on ice to block non-specific binding sites. Subsequently, cells were incubated for $30 \mathrm{~min}$ with the following antibodies: CD4-PerCP Cy5.5, CCR6-PE (both from Biolegend, San Diego, CA, USA) CD8a-PECy7, CD69-PE, CD25Alexa Fluor 488, CD3-PerCP Cy5.5, CD27-PE, CD19-APC and B220-FITC (all from Thermo Fisher). For intracellular staining, cells were first fixated and permeabilized with Foxp3 Staining buffer set (Thermo Fisher) according to manufacturer's protocol, followed by incubation with Foxp3-PECy7 (Thermo Fisher), ROR $\gamma$ T-Alexa Fluor 647 (BD) or Tbet-eFluor 660 (Biolegend). Dead cells were excluded using Fixable Viability Dye eFluor ${ }^{\circledR} 780$ (Thermo Fisher). Stained cells were measured by FACS Canto II (BD Biosciences) and analyzed using Flowlogic software version 7 (Inivai Technologies, Mentone, VIC, Australia).

\subsubsection{Generation of Bone Marrow-Derived Dendritic Cells (BMDC)}

Naïve mice (donor mice) were sacrificed on day 24 and bone marrow cells were isolated from the femur as previously described $[23,30,31]$. Bone marrow cells were resuspended in RPMI 1640 supplemented with 10\% FCS, penicillin $(100 \mathrm{U} / \mathrm{mL})$ and streptomycin $(100 \mu \mathrm{g} / \mathrm{mL})$. Bone marrow cell suspensions $\left(0.5 \times 10^{6} \mathrm{cell} / \mathrm{mL}\right)$ were cultured in the presence of $20 \mathrm{ng} / \mathrm{mL}$ recombinant mouse granulocyte macrophage colony-stimulating factor (GM-CSF) (Prospec, Rehovot, Israel) in a petri dishes (Corning). On day 3, medium was refreshed, and on day 6, bone marrow derived-dendritic cells (BMDC) were harvested. Immature BMDC were then loaded with the Influvac vaccine $(0.9 \mu \mathrm{g} / \mathrm{mL})$ and incubated for $24 \mathrm{~h}\left(37^{\circ} \mathrm{C}, 5 \% \mathrm{CO}_{2}\right)$.

\subsubsection{Ex Vivo Re-Stimulation Assay}

Spleens were aseptically removed and single cell suspensions were obtained as described in Section 2.2.4. Splenocytes $\left(5 \times 10^{6}\right)$ were co-cultured with BMDC $\left(5 \times 10^{5}\right)$ either or not loaded with Influvac in U-bottom 96-well plates at $37^{\circ} \mathrm{C}, 5 \% \mathrm{CO}_{2}$. After 5 days of incubation, supernatants were collected and stored at $-20^{\circ} \mathrm{C}$ for cytokine analysis. IFN $\gamma$, IL-13 (both from R\&D) were measured by means of ELISA according to the protocol described in Section 2.1.4. for galectin-4 and -9. Purified rat anti-mouse antibodies $(1 \mu \mathrm{g} / \mathrm{mL}$ for IFN $\gamma$ and $2 \mu \mathrm{g} / \mathrm{mL}$ for IL-13), recombinant mouse cytokines and biotinylated rat antimouse antibodies $(1 \mu \mathrm{g} / \mathrm{mL}$ for IFN $\gamma$ and $400 \mathrm{ng} / \mathrm{mL}$ for IL-13) were purchased from BD Biosciences. TNF $\alpha$ (Biolegend), IL-10 and IL-17A concentrations (both from Thermo fisher) were measured by ELISA according to manufacturer's protocol.

\subsection{8. qPCR Analysis of Gene Expression}

Ileum and colon samples from mice sacrificed after DTH measurement were collected in RNA later (Invitrogen) and stored in $-80{ }^{\circ} \mathrm{C}$ until mRNA isolation. Tissues were homogenized and RNA was isolated using a NucleoSpin ${ }^{\circledR}$ RNA Plus kit (Macherey-Nagel, Düren, Germany) in combination with DNAse (Qiagen, Hilden, Germany) to remove contaminating DNA. Complementary DNA (cDNA) was synthesized using an iScript ${ }^{\mathrm{TM}}$ cDNA synthesis kit (Bio-Rad) according to the manufacturer's protocol. Quantitative 
analysis was performed on a CFX96 real-time PCR detection system with the use of IQ $^{\text {TM }}$ SYBR $^{\circledR}$ Green Supermix (both from Bio-Rad). Commercially available primers for TGF $\beta 1$, TGF $\beta 3$, ROR $\gamma$, Foxp3, TNF $\alpha$, IL-10, Tbx21, galectin-3, -4 and -9 , were obtained and GAPDH and PPIP5K1 (all from Qiagen) were used as reference genes. Relative mRNA

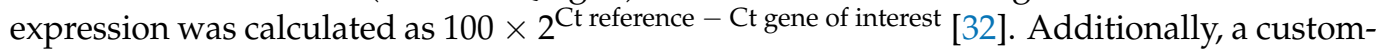
designed primer (Table 1) was used for, TNF $\alpha$ (Biolegio, Nijmegen, The Netherlands), previously validated [23].

Table 1. Sequence of custom-made primer and corresponding accession number.

\begin{tabular}{cccc}
\hline Gene ID & Accession Number & Forward Primer Sequence $\left(\mathbf{5}^{\prime}-\mathbf{3}^{\prime}\right)$ & Reverse Primer Sequence $\left.\mathbf{( 5}^{\prime}-\mathbf{3}^{\prime}\right)$ \\
\hline TNF $\alpha$ & NM_013693.3 & AACGGCATGGATCTCAAAGA- & TTTCTCCTGGTATGAGATAGCAAATC \\
\hline
\end{tabular}

\subsection{Statistical Analysis}

All statistical analyses were done using GraphPad Prism software (San Diego, CA, USA). Data were transformed if they did not fit normal distribution prior to ANOVA analysis. IEC/PBMC co-culture datasets were analyzed using one-way ANOVA followed by Bonferroni's post-hoc test. The sample size of the in vivo vaccination study was calculated based on the DTH results from previous studies. The in vivo datasets from the vaccination model were analyzed using a one-way ANOVA followed by Bonferroni's test with selected pairs. Probability values of $p<0.05$ were considered significant.

\section{Results}

\subsection{Exposure of IEC to FP Enhances Th1- and Th17-Type Cytokines Iin the} IEC/PBMC Co-Culture

A model to study the crosstalk between IEC and innate as well as adaptive immune cells was used to investigate the immunomodulatory effects of FP. Therefore, IECs were apically exposed to FP and basolaterally to $\alpha \mathrm{CD} 3 / \mathrm{CD} 28$-activated PBMC for $24 \mathrm{~h}$, after which cytokines were analyzed. Exposure of IEC to activated PBMC and $0.25 \%$ or $0.5 \%$ FP resulted in significantly increased Th1-type IFN $\gamma$ and TNF $\alpha$ concentrations as compared to medium (Figure 1A,B). Th17-type IL-17A concentrations were significantly upregulated upon exposure to $0.5 \%$ FP, as compared to medium (Figure 1C). Meanwhile, Th2-type IL-13 and regulatory-type IL-10 and galectin-9 concentrations were not affected upon exposure to FP in the IEC/PBMC model (Figure 1D-F). The secretion of Th1- and Th17-type cytokines was promoted in the IEC/PBMC model upon exposure to FP.

\subsection{IEC-Derived Galectin-3, -4 and-9 after IEC/PBMC Co-Culture}

In order to analyze the epithelial cell responsiveness, after the IEC/PBMC co-culture, the IECs were washed and kept in incubation with fresh medium for an additional $24 \mathrm{~h}$, after which IEC-derived mediator release was measured. Due to their involvement in the regulation of many immune processes, IEC-derived galectin concentrations were studied in the basolateral compartment. Exposure to $0.5 \%$ FP resulted in significantly increased IECderived galectin-3, -4 and -9 (Figure 2A-C) as compared to control or $0.25 \%$ FP. IEC-derived galectin-9 was significantly increased upon exposure to $0.25 \%$ FP (Figure 2C). Meanwhile, a tendency towards increased epithelial-derived galectin- 3 and $-4(p=0.08$ and $p=0.06$ respectively, Figure 2A,B) was observed upon exposure to $0.25 \% \mathrm{FP}$, compared to medium. Another regulatory mediator known to be produced by epithelial cells is TGF $\beta 1$, but FP did not enhance TGF $\beta 1$ concentrations above medium background levels (data not shown). 
A

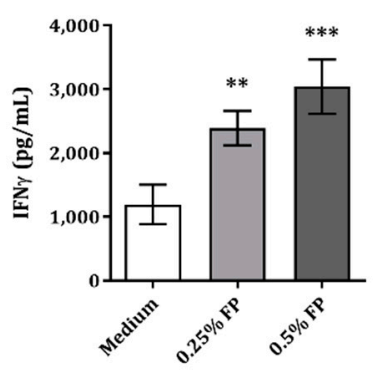

D

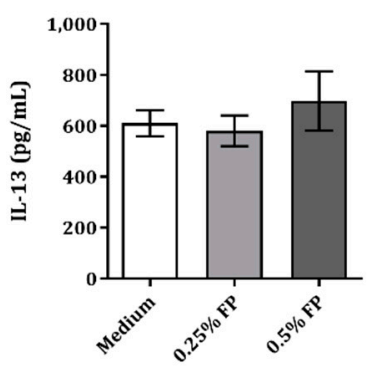

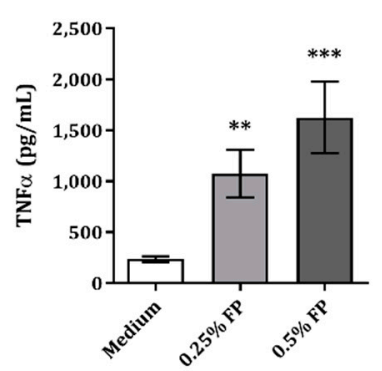

E

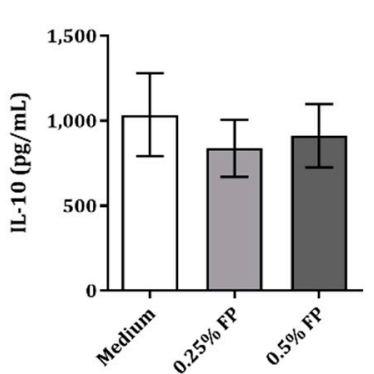

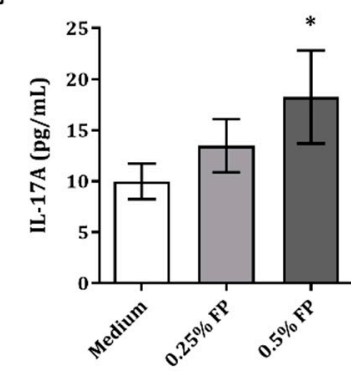

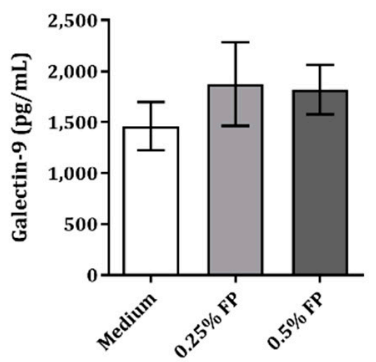

Figure 1. Cytokine release in IEC/PBMC co-culture. IECs were apically exposed to $0.25 \%$ or $0.5 \% \mathrm{FP}$ and basolaterally to $\alpha \mathrm{CD} 3 / \mathrm{CD} 28$-activated PBMC. IFN $\gamma(\mathbf{A})$, TNF $\alpha$ (B), IL-17A (C) IL-13 (D), IL-10 (E) and galectin-9 (F) concentrations were measured in the basolateral supernatant after $24 \mathrm{~h}$ co-culture. Data are represented as mean \pm SEM of 5-6 independent PBMC donors. Significant differences are shown as ${ }^{*} p<0.05,{ }^{* *} p<0.01,{ }^{* * *} p<0.001$.

A

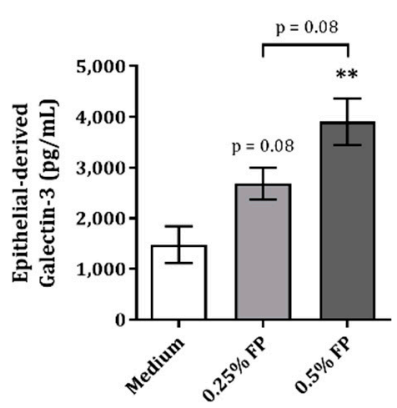

D

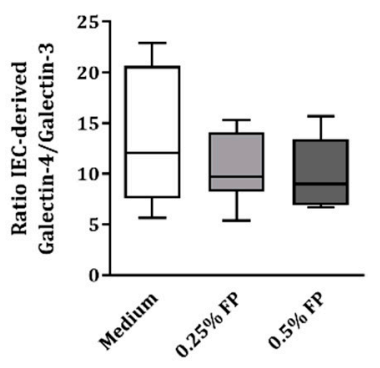

B

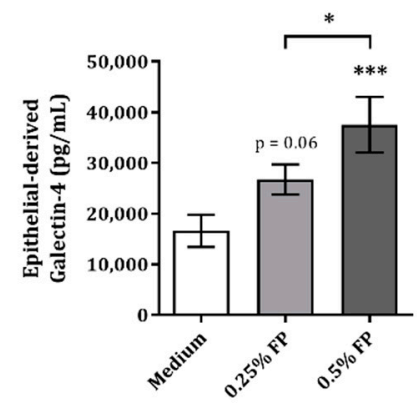

E

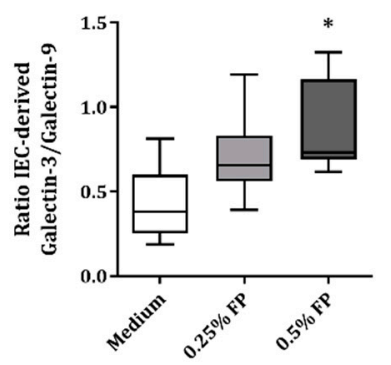

C

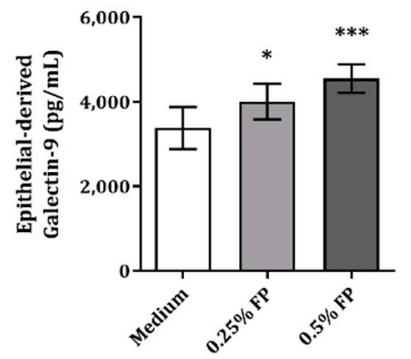

F

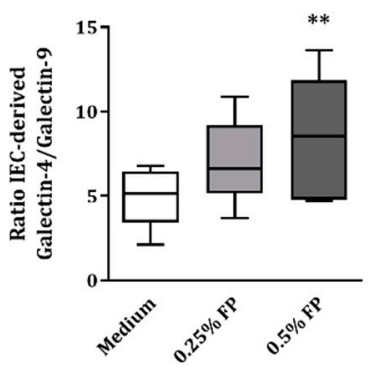

Figure 2. Epithelial-derived galectin release after IEC/PBMC co-culture. IECs were apically exposed to $0.25 \%$ or $0.5 \%$ FP and basolaterally to $\alpha \mathrm{CD} 3 / \mathrm{CD} 28$-activated PBMC for $24 \mathrm{~h}$. After IEC/PBMC co-culture, IECs were washed and incubated with fresh medium for additional $24 \mathrm{~h}$ to measure epithelial-derived galectin-3 (A), -4 (B) and -9 (C) concentrations. Additionally, the ratios between epithelial-derived galectins are shown. Shown are the galectin- 4 and -3 ratio (D), the galectin-3 and -9 ratio $(\mathbf{E})$ and the galectin -4 and -9 ratio $(\mathbf{F})$. Data are represented as mean \pm SEM of 5-6 independent PBMC donors. Significant differences are shown as ${ }^{*} p<0.05,{ }^{* *} p<0.01,{ }^{* * *} p<0.001$. 
As the rise in galectin-3 and -4 release upon $0.5 \%$ FP exposure appeared greater than the rise in galectin-9 release, the ratios between IEC-derived galectins was calculated to illustrate the balance between these inflammatory and regulatory galectins. No significant effect was found in the ratio of galectin-4 over galectin-3 (Figure 2D), whereas the ratio of galectin-3 over galectin-9 (Figure 2E) and galectin- 4 over galectin-9 (Figure 2F) showed a significant increase in the $0.5 \%$ FP conditions. Hence, exposure of IEC to FP in the IEC/PBMC model resulted in significantly increased IEC-derived galectin-3, -4 and -9 , while the ratio of galectin- 4 over galectin- 9 as well as the ratio of galectin- 3 over galectin- 9 significantly increased upon exposure to $0.5 \%$ FP.

In light of the immunomodulatory profile shown by FP in the IEC/PBMC model, further studies were done to determine the capacity of FP on the improvement of influenza vaccination responses in vivo.

\subsection{Dietary Intervention with FP Improves the Vaccine-Specific DTH Response}

On day 30, the C57BL/6OlaHsd mice received a subcutaneous injection with the vaccine in the ear pinnae, after which, on day 31 , the ear swelling was measured as DTH to determine the T-cell-dependent cellular response to vaccination. A significant increase in the influenza-specific DTH response was seen in all vaccinated mice as compared to the non-vaccinated sham mice (Figure 3B). The DTH response did not differ between the vaccinated mice receiving lactose diet as compared to vaccinated mice receiving control diet (Figure 3B). Although $0.5 \%$ FP did increase the DTH reaction compared to its appropriate lactose control, it did not reach the level of significance. However, increasing the dose to $2.5 \%$ FP significantly enhanced the DTH response compared to its appropriate lactose control group (Figure 3B).

A

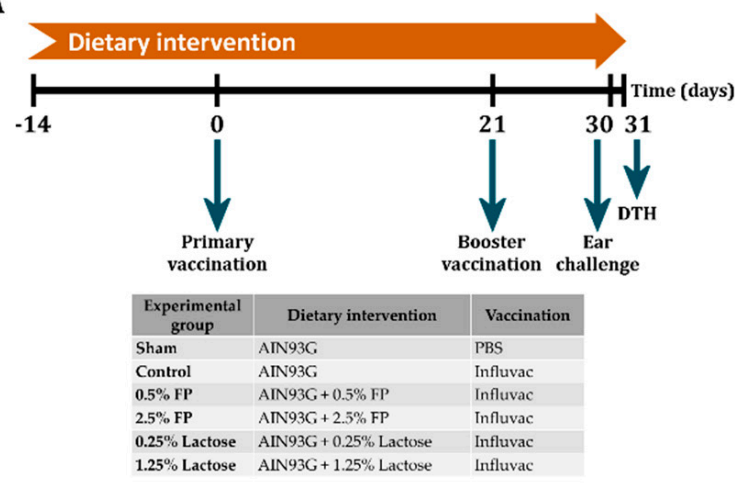

C

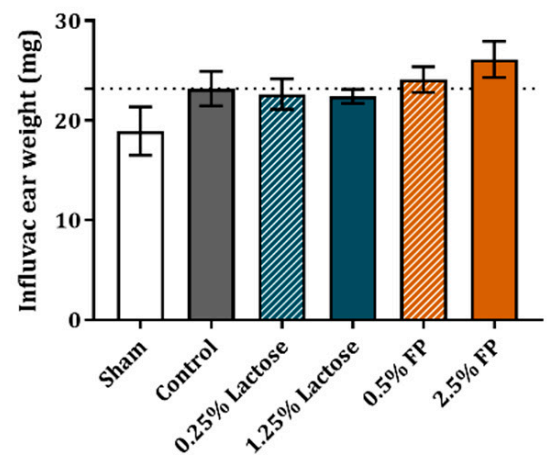

B

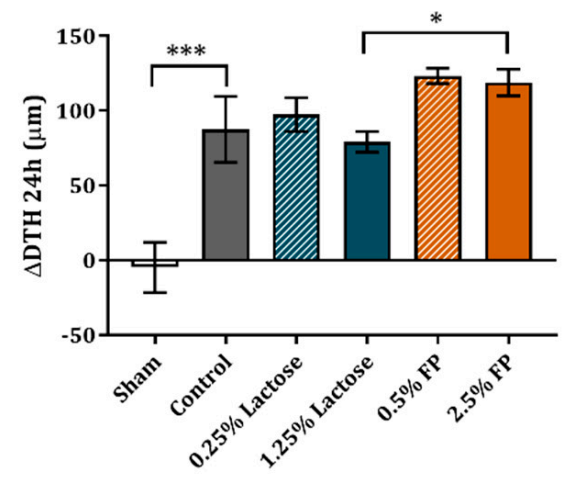

D

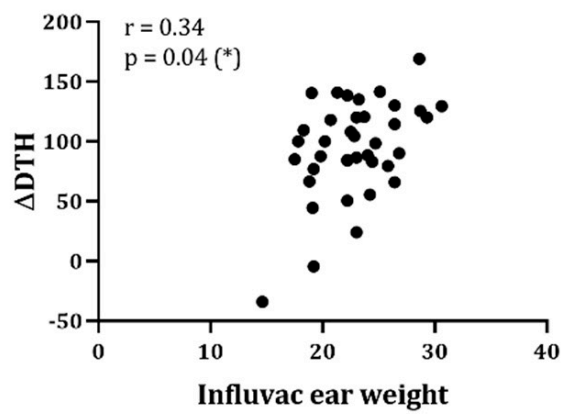

Figure 3. The effect of a dietary intervention with FP on the vaccine-specific DTH response and ear weight in an influenza vaccination model. The study design is shown (A). The increase in DTH response after ear challenge (B) and the Influvac ear weight (C) $24 \mathrm{~h}$ after challenge are shown. The spearman correlation between the $\triangle \mathrm{DTH}$ response and the ear weight is shown (D). Data are represented as mean \pm SEM of sham $(n=3)$ and vaccinated mice $(n=9)$. Significant differences are show as ${ }^{*} p<0.05,{ }^{* * *} p<0.001$. 
Although no significant effect was observed in the weight of the Influvac injected ears, a similar pattern compared to the $\triangle \mathrm{DTH}$ response was observed (Figure $3 \mathrm{C}$ ). In addition, the differences detected in the weight of the Influvac injected ears significantly correlated response with the $\triangle \mathrm{DTH}(\mathrm{r}=0.34, p=0.04)$ (Figure 3D). Due to the significantly increased vaccine-specific DTH response observed in the mice receiving 2.5\% FP diet, further analyses were done in this group and its respective lactose control group.

\subsection{Influvac-Specific Igg1 and Igg2a in Serum and Ex Vivo Cytokine Secretion}

In order to measure the humoral responsiveness to the vaccine and the impact of the dietary intervention with FP, the serum of the mice was collected and vaccine-specific IgG1 and IgG2a were measured. There was an increase in IgG1 and IgG2a levels in vaccinated mice compared to non-vaccinated sham mice (Figure $4 \mathrm{~A}, \mathrm{~B}$ ). However, vaccinespecific IgG1 and IgG2a levels were not affected by the dietary interventions with FP or lactose (Figure 4A,B).

A

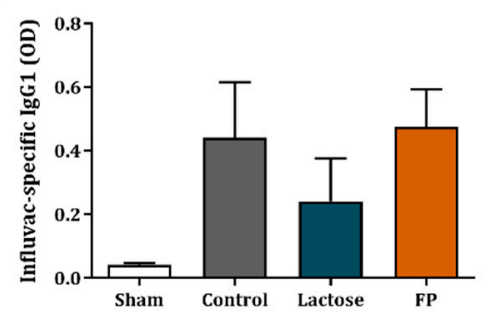

C

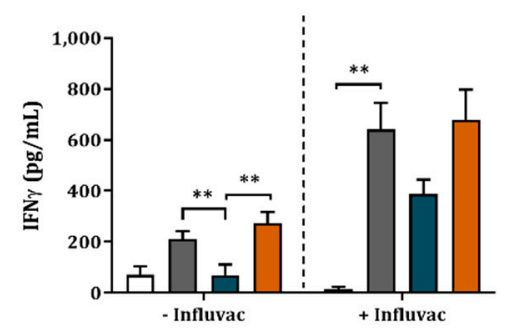

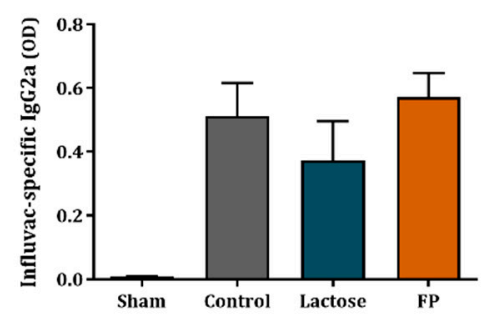

D

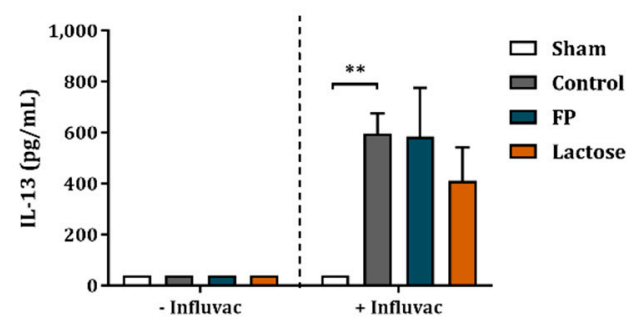

Figure 4. Serum immunoglobulins and cytokine production after ex vivo re-stimulation with influenza-loaded BMDCs. Influvac-specific IgG1 (A) and IgG2a (B) concentrations were measured in the serum. Additionally, BMDCs were obtained from donor mice and loaded with or without $0.9 \mu \mathrm{g} / \mathrm{mL}$ Influvac for $24 \mathrm{~h}$. On day 31, BMDCs were co-cultured with fresh spleen cell suspensions from sham as well as vaccinated mice for 5 days, after which the supernatants of the co-culture were collected and the cytokine secretion was analyzed. IFN $\gamma(\mathbf{C})$ and IL-13 (D) concentrations are shown. Data are represented as mean \pm SEM of sham $(n=3)$ and vaccinated mice $(n=9)$. Significant differences are show as, ${ }^{* *} p<0.01$.

In order to investigate the effect of FP in the systemic vaccination response both Tand B-cell subsets of the spleen and MLN were analyzed by flow cytometry. Regulatory T-cells were identified as $\mathrm{CD}^{+} \mathrm{CD} 25^{+} \mathrm{Foxp}^{+}$, $\mathrm{ROR} \gamma$ positive cells were identified as $\mathrm{CD}^{+} \mathrm{CCR} 6{ }^{+} \mathrm{ROR} \gamma^{+}$and, lastly, activated Th1 type cells were identified as CD4 ${ }^{+} \mathrm{CD} 69^{+} \mathrm{Tbet}^{+}$. Activated B-cells were identified as $\mathrm{CD} 3^{-} \mathrm{CD} 19^{+} \mathrm{B} 220^{+} \mathrm{CD} 27^{+}$and activated $\mathrm{CD} 8^{+} \mathrm{T}^{-}$-cells as $\mathrm{CD}^{+} \mathrm{CD}^{+} 9^{+}$.

In the spleen, the frequency of regulatory T-cells was significantly increased, and the frequency of activated Th1-type cells was decreased in vaccinated mice as compared to non-vaccinated mice; however, this was not affected by the dietary intervention (Figure S1). Dietary intervention with FP did also not have an effect in the T- and B-cell frequencies of the spleen, even though in the lactose control group the frequency of activated B- and CD8 T-cells was increased as compared to the control diet (Figure S1). In the MLN, no significant differences were found in either T- or B-cell populations of vaccinated mice as compared to non-vaccinated mice. Dietary intervention with FP also did not affect the Tand B-cell frequencies in the MLNs (Figure S1). The frequency of Th1 positive T-cells in the 
MLNs was significantly increased in the mice receiving lactose as compared to control and FP (Figure S1).

Using an ex vivo re-stimulation model, vaccine-specific T-cell responses were investigated. Splenocyte cell suspensions were co-cultured with BMDC either loaded or not with Influvac for 5 days. After co-culture, the cytokine concentrations were analyzed. Coculture of splenocytes with non-loaded BMDC resulted in a relatively small non-specific background increase of IFN $\gamma$ concentrations, while IFN $\gamma$ was significantly increased when using Influvac loaded BMDC (Figure 4C). Similarly, increased IL-13 concentrations were found in co-cultures of splenocytes from vaccinated mice as compare to non-vaccinated mice in co-culture with Influvac-loaded BMDC (Figure 4D). Dietary intervention with lactose or FP did not further increase IFN $\gamma$ and IL-13 concentrations (Figure $4 \mathrm{C}, \mathrm{D}$ ). TNF $\alpha$, IL-17A and IL-10 concentrations were under detection limit.

Dietary intervention with FP did not have an effect the Influvac-specific IgG1 and IgG2a levels or the frequency of B-cell populations in spleen of MLNs. Influenza-specific ex vivo re-stimulation induced IFN $\gamma$ secretion was not altered in the FP group.

\subsection{Shift in Th17/T-Regulatory Mrna Expression in Ileum}

The effect of dietary intervention with FP was also assessed locally in the intestine. Therefore, ileal as well as colonic sections were subjected to qPCR analysis, which obtained detectable levels of ROR $\gamma$, TGF $\beta 1$ and TGF $\beta 3$. Meanwhile, Foxp3, TNF $\alpha$, IL-10 and Tbx21 were below detection limits. Although no effects were observed in the relative mRNA abundance of ROR $\gamma$ (Figure 5A), the TGF $\beta 1$ relative mRNA abundance was decreased in the ileum of vaccinated mice as compared to non-vaccinated mice (Figure 5B). Even though in the FP diet group an increasing pattern of $\mathrm{ROR} \gamma$ mRNA expression and a decreasing pattern of TGF $\beta 1$ expression was shown, this did not reach statistical significance (Figure $5 \mathrm{~A}, \mathrm{~B}$ ). The TGF $\beta 3 \mathrm{mRNA}$ expression did tend to decrease in the ileum of the mice receiving FP diet as compared to control (Figure 5C).

A

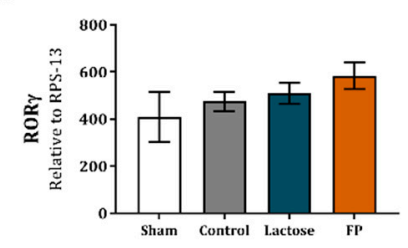

B

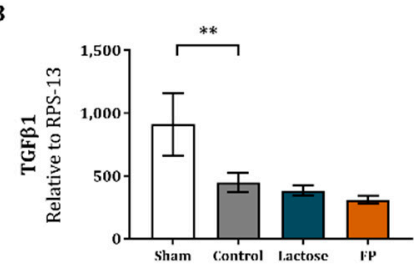

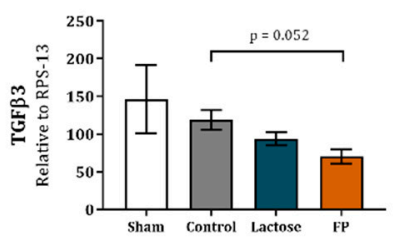

G

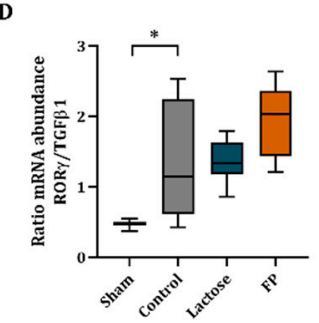

E

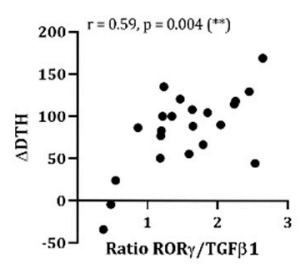

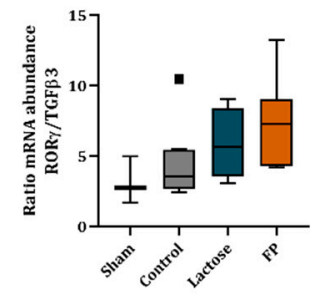

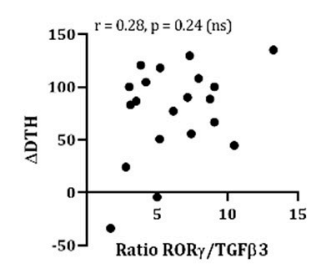

Figure 5. Relative mRNA expression in ileum and correlation with $\triangle \mathrm{DTH}$. Relative mRNA expression of ROR $\gamma(\mathrm{A})$, TGF $\beta 1$ (B) and TGF $\beta 3$ (C) were measured in the ileum using RT-qPCR. ROR $\gamma /$ TGF $\beta$ ratios were calculated to represent Th17/regulatory balance in ileum. The ratio of ROR $\gamma$ over TGF $\beta 1$ mRNA abundance (D) and ROR $\gamma$ over TGF $\beta 3$ (F) are shown. Additionally, Spearman correlations of $\triangle \mathrm{DTH}$ and ROR $\gamma$ over TGF $\beta 1$ ratio (E) as well as correlations of $\triangle \mathrm{DTH}$ and ROR $\gamma$ over TGF 33 ratio $(\mathbf{G})$ are shown. Data are represented as mean \pm SEM of sham $(n=3)$ and vaccinated mice $(n=9)$. Significant differences are show as ${ }^{*} p<0.05,{ }^{* *} p<0.01$.

Additionally, to represent the Th17 immune versus regulatory balance in the ileum, the ratio of Th17 marker ROR $\gamma$ and regulatory marker TGF $\beta$ was calculated (ROR $\gamma / \mathrm{TGF} \beta 1$ and ROR $\gamma /$ TGF $\beta 3$ ). The ROR $\gamma /$ TGF $\beta 1$ ratio was significantly increased in vaccinated mice as compared to non-vaccinated mice (Figure 5D). No significant effect was found in 
ROR $\gamma /$ TGF $\beta 1$ ratio between control and FP groups (Figure 5D), although the FP showed a shift towards ROR $\gamma$ over TGF $\beta 1$ compared to the control and lactose groups. In addition, the correlation between ROR $\gamma /$ TGF $\beta 1$ ratio and $\triangle \mathrm{DTH}$ response was studied, which showed a significant positive correlation $(\mathrm{r}=0.59, p=0.004$, Figure 5E). No effect was found in the ROR $\gamma / \mathrm{TGF} \beta 3$ ratio (Figure $5 \mathrm{~F}$ ) and no correlation was found between the $\mathrm{ROR} \gamma / \mathrm{TGF} \beta 3$ ratio and $\Delta \mathrm{DTH}(\mathrm{r}=0.28, p=0.24$, Figure $5 \mathrm{G})$.

In the colon, the relative mRNA abundance of ROR $\gamma$ in vaccinated mice was decreased as compared to non-vaccinated mice (Figure S2). No effects were found in the relative mRNA abundance of galectin-3, galectin-4, galectin-9, TGF $\beta 1$ or TGF $\beta 3$ in vaccinated mice as compared to non-vaccinated mice (Figure S2). TGF $\beta 3$ mRNA expression was significantly increased by FP and lactose, as compared to control. The TGF $\beta 1, \operatorname{ROR} \gamma$ and galectin-3, -4 , and -9 mRNA abundance was not affected upon dietary intervention with FP (Figure S2).

\subsection{Galectin-3, -4 and -9 Mrna Expression in Ileum and Concentrations in Serum}

Besides the immune markers, the impact of the dietary intervention by FP was studied locally on the gene expression of galectins in the ileum and colon. No effect of the vaccination or the FP diet was found in the relative mRNA abundance of galectin-3, -4 and -9 (Figure S3).

Galectin concentrations were also measured in the serum of the mice. No significant differences were observed in galectin- $3,-4$ and -9 concentrations in the serum of vaccinated mice as opposed to non-vaccinated mice (Figure 6A-C). Galectin-3 and -4 concentrations were not affected upon dietary intervention with FP or lactose as compared to control group. However, for the group fed the FP diet, an increasing pattern was observed (Figure 6A,B), while galectin-9 concentrations in serum were reduced as compared to both the control and lactose group (Figure 6C). As a result, the galectin-4/galectin-9 as well as the galectin3 /galectin-9 ratio were significantly increased (Figure $6 \mathrm{D}$,E, respectively) in the FP group as compared to the control and lactose group. The galectin- $4 /$ galectin-3 ratio was not affected (Figure S4).

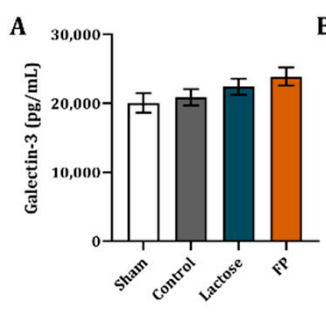

$\mathbf{F}$

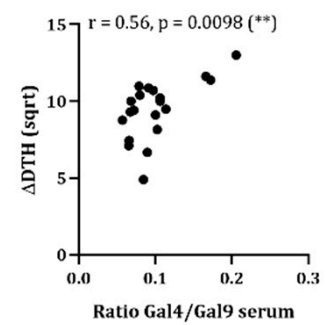

B

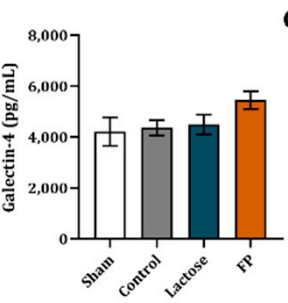

G

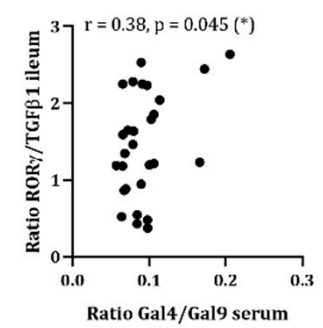

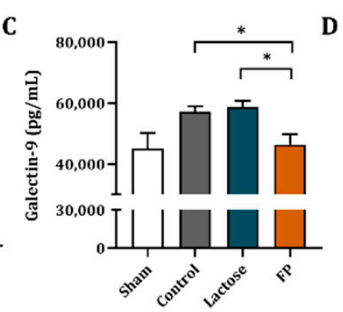

H

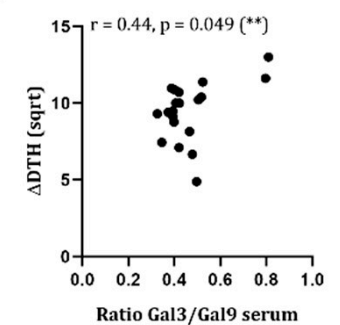

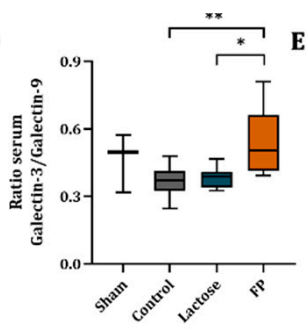

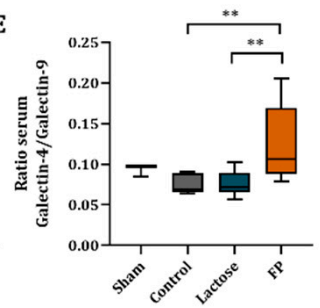

I

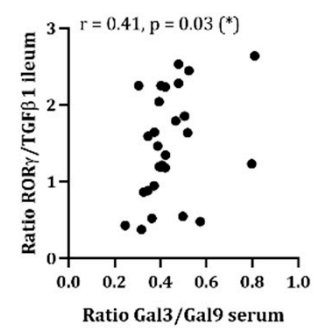

Figure 6. Galectin-3, -4 and -9 concentrations in serum. Serum galectin-3 (A), galectin-4 (B) and galectin-9 (C) concentrations were measured. The galectin-4/galectin-9 ratio (D) and galectin-3/galectin-9 ratio (E) are shown. Serum galectin ratios were correlated to $\triangle \mathrm{DTH}$ and ROR $\gamma / \mathrm{TGF} \beta 1$ ratio in the ileum. Spearman correlation of galectin- $4 /$ galectin-9 ratio and $\triangle \mathrm{DTH}$ is shown (F). Galectin-4/galectin-9 ratio was also correlated with ROR $\gamma / \mathrm{TGF} \beta 1$ ratio using a Pearson correlation (G). Additionally, correlations of galectin-3/galectin-9 ratio and $\triangle \mathrm{DTH}(\mathbf{H})$ as well as to the ROR $\gamma / \mathrm{TGF} \beta 1$ ratio $(\mathrm{I})$ were calculated using a Pearson and Spearman correlation, respectively. Data are represented as mean $\pm \operatorname{SEM}$ of $\operatorname{sham}(n=3)$ and vaccinated mice $(n=9)$. Significant differences are show as ${ }^{*} p<0.05,{ }^{* *} p<0.01$. 
In order to connect the effects observed, such as the increase in DTH as well as of $\operatorname{ROR} \gamma / \mathrm{TGF} \beta 1$ ratio in the intestine, with the serum galectin concentrations, the galectin4/galectin-9 and galectin-3/galectin-9 ratio were correlated to ROR $\gamma / \mathrm{TGF} \beta 1$ ratio in the ileum as well as to $\triangle \mathrm{DTH}$. The serum galectin- 4 over galectin- 9 ratio showed a positive correlation to $\triangle \mathrm{DTH}(\mathrm{r}=0.56, p=0.0098$, Figure $6 \mathrm{~F})$ and to the ratio of ROR $\gamma / \mathrm{TGF} \beta 1$ mRNA expression in the ileum $(\mathrm{r}=0.38, p=0.045$, Figure $6 \mathrm{G})$. Furthermore, the serum galectin-3/galectin-9 ratio was found to be significantly correlated to $\triangle \mathrm{DTH}(\mathrm{r}=0.44$, $p=0.049$, Figure $6 \mathrm{H}$ ) as well as to the ratio of ROR $\gamma / \mathrm{TGF} \beta 1 \mathrm{mRNA}$ expression in ileum $(\mathrm{r}=0.41, p=0.03$, Figure 6I). Meanwhile, ROR $\gamma / \mathrm{TGF} \beta 3$ ratio did not show a significant correlation (Figure S4) with serum galectin-4/galectin-9 ratio $(\mathrm{r}=0.25, p=0.2)$ or galectin3 /galectin-9 ratio $(r=0.3, p=0.12)$.

Dietary intervention with FP significantly reduced galectin-9 concentrations in the serum, which contributed to significantly increased galectin- 4 over galectin- 9 as well as galectin-3 over galectin- 9 ratios. This shift in serum galectin- 4 /galectin- 9 and galectin$3 /$ galectin-9 correlated with an increase in DTH as well as to an increase in the ratio of ROR $\gamma / T G F \beta 1$ mRNA expression in the ileum.

\section{Discussion}

Postbiotics are known to improve immune as well as gut parameters in healthy and pre-term infants [4]. An in vitro co-culture model developed to study the crosstalk of IEC and immune cells was used to investigate the immunomodulatory capacity of FP derived from the fermentation of a milk matrix with Bifidobacterium breve C50 and Streptococcus thermophilus 065 (Lactofidus ${ }^{\mathrm{TM}}$ ). Studies using the same model showed the immunomodulatory capacity of non-digestible oligosaccharides in association with CpG ODN, a TLR9 agonist, under inflammatory conditions $[21,22,28]$. In the current study, apical exposure of IEC to FP, and basolaterally to $\alpha$ CD3/CD28-activated PBMC, resulted in significantly increased Th1-type IFN $\gamma$ and TNF $\alpha$, as well as Th17-type IL-17A concentrations. Moreover, Th2-type IL-13, regulatory-type IL-10 and galectin-9 were not affected, which indicates that FP can boost the adaptive immunity by promoting Th1- and Th17-type cytokine release in this model. Unlike the studies with specific non-digestible oligosaccharides, namely a 9:1 mixture of short-chain galacto- and fructo-oligosaccharides (GF) [24,28] or 2'-fucosyllactose (2'-FL) [22] and TLR9 agonist CpG ODN, FP did not boost IL-10 nor lowered IL-13, which evidences selective FP immunomodulatory properties. However, as opposed to non-digestible oligosaccharides in association with CpG ODN, FP promoted a strong Th1- and Th17-type response with less regulatory component already in the absence of CpG ODN, again emphasizing the relevance of the particular properties of FP.

IEC-derived galectin-9 has been identified as a key factor contributing to immunomodulation by previous studies using the IEC/PBMC model $[24,25,28]$. For the purpose of this study, we used the HT-29 cell line as a model for IEC. HT-29 have previously been shown to differentially respond to diverse microbial or immune triggers mimicking responses in human intestinal biopsies [33,34]. The HT-29 also were shown to have a similar immunomodulatory effect compared to the differentiated T84 epithelial cell model when co-cultured in transwells with PBMC. Similar to HT-29, also the T84 cell line expressed and secreted galectin-9 upon apical exposure to TLR9 agonist CpG ODN, resulting in increased IFN $\gamma$ secretion by the underlying PBMC [35]. The involvement of IEC-derived and/or systemic galectin-9 as an immunomodulatory factor has also been substantiated in dietary intervention studies done in food allergy prevention models as well as in human infants [26,27]. The confirmation of findings in the HT29/PBMC co-culture model in (pre)clinical settings further validates the choice of HT-29 as a model for intestinal epithelial cells to study the crosstalk between IEC and immune cells.

Besides galectin-9, the association of IEC-derived galectin- 3 and -4 in promoting immunomodulatory effects in the IEC/PBMC model was already reported upon exposure to non-digestible oligosaccharides and $\mathrm{CpG}$ ODN [22]. Galectins are carbohydrate-binding proteins that function to modulate innate and adaptive immune responses. Secreted by 
epithelial as well as immune cells, galectins are key players in inflammatory and regulatory immune processes [36]. Galectin- 3 as well as -4 were shown to have anti-inflammatory as well as pro-inflammatory activities in diverse immune processes $[37,38]$. Besides its role in the stabilization of lipid rafts, apical protein trafficking and cell adhesion [38], galectin-4 was shown to exacerbate intestinal inflammation by stimulating CD4+ T-cells to produce IL-6 in a murine colitis model [39]. Contrarily, galectin-4 has also been described as an anti-inflammatory agent by selectively modulating T-cell responses in an experimental colitis model [40]. Similarly, galectin-3 also showed anti-inflammatory properties by contribution to ameliorate mucosal inflammation in a murine colitis model [41]. In this regard, galectin-9 has been shown to regulate inflammatory responses and collaborates with TGF $\beta$ to instruct regulatory T-cell development $[42,43]$. In the current study, exposure to $0.5 \% \mathrm{FP}$ resulted in significantly increased IEC-derived galectin-3, -4 as well as -9 , which indicates that not only galectin-9, but also galectin-3 and -4 might be involved in the immunomodulatory effects promoted by FP. However, upon exposure to FP, the ratio of IEC-derived galectin- 3 or galectin- 4 over galectin- 9 were significantly increased, suggesting a more immunostimulatory over regulatory profile induced by FP.

Due to the ability of FP in boosting the adaptive immunity by promoting Th17and Th1-type cytokines in the IEC/PBMC model, the capacity of a diet containing FP in improving a vaccination immune response was studied. Thereby, an established in vivo influenza vaccination model was used [19] in which mice received a dietary intervention with FP or lactose as a control. Dietary intervention with non-digestible oligosaccharides can modulate the vaccine-specific DTH response, a Th1-related parameter [20-23,29]. In line with these studies, here, we show that the vaccine-specific DTH was increased, although not significantly, upon dietary intervention with $0.5 \%$ FP compared to the lactose control diet. However, increasing the dose of the dietary intervention to $2.5 \%$ FP resulted in a significant increase in the DTH response. The increase in vaccine-specific DTH in vivo and the increase in Th1 and Th17-type cytokines as well as the increased IEC-derived galectin-3 or galectin- 4 over galectin-9 ratio seen in the IEC/PBMC model in vitro highlight the ability of FP to support Th1- and Th17-type immunity possibly in association with the modulation of galectin expression.

Despite the increase in DTH observed in mice receiving the FP-containing diet, the vaccine-specific IgG1 and IgG2a levels were not affected by the dietary intervention with FP. Previous studies described similar effects in mice receiving a GF supplemented diet [19]. Contrarily, significantly increased IgG1 and IgG2a levels were found in mice receiving a $2^{\prime}$-FL supplemented diet [23]. This suggests that FP supplementation might affect the T-cell rather than B-cell immune responses, emphasizing the selective mechanisms derived from different dietary interventions.

Changes in the phenotype of T- and B-cells were studied in the spleen and MLNs of the mice and Influvac re-stimulation was performed ex vivo. The increase in DTH did not translate into an increase in the percentage of Th1 or Th17 type T-cells in the spleen or MLN, measured as $\mathrm{CD}_{6} 9^{+} \mathrm{Tbet}^{+}$or $\mathrm{CCR} 6{ }^{+} \mathrm{ROR} \gamma^{+}$, nor enhanced Influvac-specific IFN $\gamma$ release, suggesting that such an effect is obtained through distinct mechanisms.

Regulatory T-cells as well as Th17 cells are found in intestinal mucosal immune responses and are known to protect the host from exaggerated effector T-cell responses. Th17 cells were described to have a critical role in host defense and vaccine-induced memory immune responses, by promoting the recruitment of Th1-type cells through the upregulation of chemokines, among other processes [44,45]. TGF $\beta$ is a key mediator involved in regulating the differentiation of naïve T-cells into regulatory as well as Th17type. Thus, the Th17/Treg balance is key in maintaining gut immune homeostasis [46-48]. In order to study the effects of the dietary intervention with FP in the Th17/Treg balance in the intestine, ROR $\gamma$ and TGF $\beta 1$ mRNA expression of the ileum and colon were studied. Dietary intervention with FP was found to enhance the balance of ROR $\gamma$ over TGF $\beta 1$, which was calculated as a reflection of the Th17/Treg balance. This ratio was enhanced in the intestine upon systemic vaccination and correlated positively with the DTH response. 
This indicates that the modulation of the intestinal immune system by means of a dietary intervention with FP might be able to affect the systemic vaccine-specific immune response.

In addition to TGF $\beta 1$, mRNA expression of TGF $\beta 3$ was measured. Dietary intervention with 2'-FL significantly increased mRNA expression of TGF $\beta 3$ in a murine influenza vaccination model [23]. In the current study, as opposed to $2^{\prime}$-FL, relative mRNA abundance of TGF $\beta 3$ tended to decrease upon dietary intervention with FP as compared to control, showing a similar trend as seen for TGF $\beta 1$ mRNA expression. However, as opposed to the $\mathrm{ROR} \gamma / \mathrm{TGF} \beta 1$ ratio, the ROR $\gamma / \mathrm{TGF} \beta 3$ ratio and $\triangle \mathrm{DTH}$ were not correlated. Therefore, in addition to these immune markers, the role for galectins in the immunomodulatory effect of the FP diet were further studied.

Circulating galectins are being considered as relevant biomarkers for supporting the diagnosis of several chronic disorders [49]; even in response to viral infections such as influenza, plasma galectin-9 levels were found to be a relevant biomarker for disease prognosis [50]. In order to determine the relevance of circulating galectins in our model and link them to the epithelial-derived galectin concentrations seen in vitro, serum concentrations of galectin-3, -4 and -9 were studied. Dietary intervention with FP showed decreased galectin-9 concentrations, while no effects were found in galectin- 3 and -4 concentrations. Indeed, galectin-3, -4 and -9 could also be measured in the intestine and serum of the mice in the vaccination model. Even though different responses were observed regarding the modulation of galectin levels in the murine vaccination model as compared to the in vitro IEC/PBMC co-culture, these might derive from the specific conditions mimicked in the models. While the IEC/PBMC co-culture represents a generic inflammation in vitro, the vaccination model focuses on antigen-specific immune responses in vivo, where more complex immune processes are studied. In spite of the distinct individual galectin concentrations observed in the serum of the mice, the galectin-4/galectin-9 ratio as well as the galectin-3/galectin-9 ratio were significantly increased upon exposure to FP in the in vivo model, similar to the IEC/PBMC co-culture model. This points towards a similar role of these types of galectins in orchestrating the immune activation and highlights the translational value of the in vitro co-culture model, which includes both IEC as well as immune cells, when studying effects on immune activation. Thus, validating the relevance of the results observed in less complex in vitro models as compared to in vivo models. Moreover, the use of in vitro models could contribute to evaluating the effects of bioactive components in order to select the most promising intervention and condition to be confirmed in animal studies, thereby contributing to the reduced use of animals.

Furthermore, the serum galectin-4/galectin-9 ratio as well as the galectin-3/galectin- 9 ratio appeared to be correlated to the increased vaccine-specific DTH. This supports the idea that the circulating galectin balance was affected by the FP diet, which as a consequence might have an effect in the vaccine-specific immune response as measured by means of the DTH response. Little is known about the role of galectins in vaccination. However, galectins have shown dual-regulatory capacities in the promotion or inhibition of viral infections depending on the surrounding conditions and localization [51,52]. This study reveals a potential involvement of systemic galectins in the improvement of vaccine immune responses. Further research is needed to study the contribution of specific subtypes of galectins in this regard.

Altogether, a Th17- and Th1-type immunomodulatory capacity of FP was shown in the IEC/PBMC model associated with increased epithelial-derived galectin-4 and galectin-3 over galectin-9. Although there was no significant difference in serum galectin-3 and -4 upon dietary intervention with FP, similar to the in vitro IEC/PBMC model, increased galectin- 4 or galectin- 3 over galectin- 9 ratios were observed in the murine influenza vaccination model. This was associated with improved vaccine immune response determined as increased DTH response. More research is needed in order to unravel possible mechanisms implicated and deciphering the bioactive components responsible for the effects observed. 
Supplementary Materials: The following are available online at https:/ / www.mdpi.com/2076-3 93X/9/3/254/s1, Figure S1: Flow cytometry analysis of T- and B-cell populations in spleen and MLN, Figure S2: Relative mRNA expression in colon, Figure S3: Ratio mRNA expression and serum galectins. Figure S4: Ratio galectin-4/galectin-3 mRNA in ileum and correlations of ROR $\gamma /$ TGF $\beta 3$ and serum galectins.

Author Contributions: Conceptualization and methodology, V.A.-M., L.E.M.W. and B.v.L.; investigation, V.A.-M., L.X., T.W., I.v.A., E.J.H. and T.L.-M.; writing-original draft preparation, V.A.-M., L.E.M.W. and B.v.L.; writing—review and editing; V.A.-M., L.X., T.W., I.v.A., E.J.H., T.L.-M., G.F., J.G., L.E.M.W. and B.v.L.; visualization, V.A.-M., L.E.M.W. and B.v.L.; supervision, V.A.-M., L.E.M.W. and B.v.L.; project administration, L.E.M.W. and B.v.L. All authors have read and agreed to the published version of the manuscript.

Funding: This research was funded by Danone Nutricia Research B.V.

Institutional Review Board Statement: The experimental procedures in this study were approved by the Ethical Committee for Animal Research of the Utrecht University and Central Commission for Animal use (approval numbers: DEC2015.II.243.038 and AVD108002016460) and complied with the principles of good laboratory animal care following the European Directive on the protection of animals used for scientific purposes.

Informed Consent Statement: Not Applicable.

Data Availability Statement: Data is contained within the article or Supplementary Materials.

Acknowledgments: The authors would like to acknowledge Mara A.P. Diks for the technical support.

Conflicts of Interest: None of the authors have a competing financial interest in relation to the presented work; J.G. is head of the division of Pharmacology, Utrecht Institute for Pharmaceutical Sciences, Faculty of Science at Utrecht University, and partly employed by Nutricia Research. T.W. and B.v.L. are employed by Nutricia Research.

\section{References}

1. Martin, R.; Nauta, A.J.; Ben Amor, K.; Knippels, L.M.J.; Knol, J.; Garssen, J. Early life: Gut microbiota and immune development in infancy. Benef. Microbes 2010, 1, 367-382. [CrossRef] [PubMed]

2. Torow, N.; Marsland, B.J.; Hornef, M.W.; Gollwitzer, E.S. Neonatal mucosal immunology. Mucosal Immunol. 2017, 10, 5-17. [CrossRef]

3. Victora, C.G.; Bahl, R.; Barros, A.J.D.; França, G.V.A.; Horton, S.; Krasevec, J.; Murch, S.; Sankar, M.J.; Walker, N.; Rollins, N.C.; et al. Breastfeeding in the 21st century: Epidemiology, mechanisms, and lifelong effect. Lancet 2016, 387, 475-490. [CrossRef]

4. Salminen, S.; Stahl, B.; Vinderola, G.; Szajewska, H. Infant Formula Supplemented with Biotics: Current Knowledge and Future Perspectives. Nutrients 2020, 12, 1952. [CrossRef] [PubMed]

5. Granier, A.; Goulet, O.; Hoarau, C. Fermentation products: Immunological effects on human and animal models. Pediatr. Res. 2013, 74, 238-244. [CrossRef]

6. Collado, M.C.; Vinderola, G.; Salminen, S. Postbiotics: Facts and open questions. A position paper on the need for a consensus definition. Benef. Microbes 2019, 10, 711-719. [CrossRef] [PubMed]

7. Aguilar-Toalá, J.E.; Garcia-Varela, R.; Garcia, H.S.; Mata-Haro, V.; González-Córdova, A.F.; Vallejo-Cordoba, B.; Hernández-Mendoza, A. Postbiotics: An evolving term within the functional foods field. Trends Food Sci. Technol. 2018, 75, 105-114. [CrossRef]

8. Wegh, C.A.M.; Geerlings, S.Y.; Knol, J.; Roeselers, G.; Belzer, C. Postbiotics and their potential applications in early life nutrition and beyond. Int. J. Mol. Sci. 2019, 20, 4673. [CrossRef] [PubMed]

9. Szajewska, H.; Skórka, A.; Pieścik-Lech, M. Fermented infant formulas without live bacteria: A systematic review. Eur. J. Pediatr. 2015, 174, 1413-1420. [CrossRef]

10. Sanders, M.E.; Merenstein, D.J.; Reid, G.; Gibson, G.R.; Rastall, R.A. Probiotics and prebiotics in intestinal health and disease: From biology to the clinic. Nat. Rev. Gastroenterol. Hepatol. 2019, 16, 605-616. [CrossRef]

11. Rodriguez-Herrera, A.; Mulder, K.; Bouritius, H.; Rubio, R.; Muñoz, A.; Agosti, M.; Lista, G.; Corvaglia, L.; Ludwig, T.; Abrahamse-Berkeveld, M.; et al. Gastrointestinal tolerance, growth and safety of a partly fermented formula with specific prebiotics in healthy infants: A double-blind, randomized, controlled trial. Nutrients 2019, 11, 1530. [CrossRef]

12. Thibault, H.; Aubert-Jacquin, C.; Goulet, O. Effects of Long-term Consumption of a Fermented Infant Formula (with Bifidobacterium breve c50 and Streptococcus thermophilus 065) on Acute Diarrhea in Healthy Infants. J. Pediatr. Gastroenterol. Nutr. 2004, 39, 147-152. [CrossRef]

13. Indrio, F.; Ladisa, G.; Mautone, A.; Montagna, O. Effect of a fermented formula on thymus size and stool pH in healthy term infants. Pediatr. Res. 2007, 62, 98-100. [CrossRef] [PubMed] 
14. Campeotto, F.; Suau, A.; Kapel, N.; Magne, F.; Viallon, V.; Ferraris, L.; Waligora-Dupriet, A.J.; Soulaines, P.; Leroux, B.; Kalach, N.; et al. A fermented formula in pre-term infants: Clinical tolerance, gut microbiota, down-regulation of faecal calprotectin and up-regulation of faecal secretory IgA. Br. J. Nutr. 2011, 105, 1843-1851. [CrossRef] [PubMed]

15. Mullié, C.; Yazourh, A.; Thibault, H.; Odou, M.F.; Singer, E.; Kalach, N.; Kremp, O.; Romond, M.B. Increased poliovirus-specific intestinal antibody response coincides with promotion of Bifidobacterium longum-infantis and Bifidobacterium breve in infants: A randomized, double-blind, placebo-controlled trial. Pediatr. Res. 2004, 56, 791-795. [CrossRef] [PubMed]

16. Morisset, M.; Aubert-Jacquin, C.; Soulaines, P.; Moneret-Vautrin, D.A.; Dupont, C. A non-hydrolyzed, fermented milk formula reduces digestive and respiratory events in infants at high risk of allergy. Eur. J. Clin. Nutr. 2011, 65, 175-183. [CrossRef]

17. Hoarau, C.; Lagaraine, C.; Martin, L.; Velge-Roussel, F.; Lebranchu, Y. Supernatant of Bifidobacterium breve induces dendritic cell maturation, activation, and survival through a Toll-like receptor 2 pathway. J. Allergy Clin. Immunol. 2006, 117, 696-702. [CrossRef]

18. Ménard, S.; Laharie, D.; Asensio, C.; Vidal-Martinez, T.; Candalh, C.; Rullier, A.; Zerbib, F.; Mégraud, F.; Matysiak-Budnik, T.; Heyman, M. Bifidobacterium breve and Streptococcus thermophilus secretion products enhance T helper 1 immune response and intestinal barrier in mice. Exp. Biol. Med. 2005, 230, 749-756. [CrossRef] [PubMed]

19. Vos, A.P.; Haarman, M.; Buco, A.; Govers, M.; Knol, J.; Garssen, J.; Stahl, B.; Boehm, G.; M'Rabet, L. A specific prebiotic oligosaccharide mixture stimulates delayed-type hypersensitivity in a murine influenza vaccination model. Int. Immunopharmacol. 2006, 6, 1277-1286. [CrossRef]

20. Vos, A.P.; Haarman, M.; Van Ginkel, J.-W.H.; Knol, J.; Garssen, J.; Stahl, B.; Boehm, G.; Rabet, L.M. Dietary supplementation of neutral and acidic oligosaccharides enhances Th1-dependent vaccination responses in mice. Pediatr. Allergy Immunol. 2007, 18, 304-312. [CrossRef]

21. Vos, A.P.; Knol, J.; Stahl, B.; M’Rabet, L.; Garssen, J. Specific prebiotic oligosaccharides modulate the early phase of a murine vaccination response. Int. Immunopharmacol. 2010, 10, 619-625. [CrossRef]

22. Schijf, M.A.; Kerperien, J.A.; Bastiaans, J.; Szklany, K.; Meerding, J.; Hofman, G.; Boon, L.; van Wijk, F.; Garssen, J.; van't Land, B. Alterations in Regulatory T Cells Induced by Specific Oligosaccharides Improve Vaccine Responsiveness in Mice. PLoS ONE 2013, 8, e75148. [CrossRef]

23. Xiao, L.; Leusink-Muis, T.; Kettelarij, N.; van Ark, I.; Blijenberg, B.; Hesen, N.A.; Stahl, B.; Overbeek, S.A.; Garssen, J.; Folkerts, G.; et al. Human milk oligosaccharide $2^{\prime}$-Fucosyllactose improves innate and adaptive immunity in an influenza-specific murine vaccination model. Front. Immunol. 2018, 9. [CrossRef] [PubMed]

24. De Kivit, S.; Kraneveld, A.D.; Knippels, L.M.J.; Van Kooyk, Y.; Garssen, J.; Willemsen, L.E.M. Intestinal epithelium-derived galectin-9 is involved in the immunomodulating effects of nondigestible oligosaccharides. J. Innate Immun. 2013, 5, 625-638. [CrossRef]

25. Ayechu-Muruzabal, V.; Overbeek, S.A.; Kostadinova, A.I.; Stahl, B.; Garssen, J.; Van't Land, B.; Willemsen, L.E.M. Exposure of intestinal epithelial cells to $2^{\prime}$-fucosyllactose and CpG enhances galectin release and instructs dendritic cells to drive Th1 and regulatory-type immune development. Biomolecules 2020, 10, 784. [CrossRef]

26. Schouten, B.; Van Esch, B.C.A.M.; Hofman, G.A.; Van Doorn, S.A.C.M.; Knol, J.; Nauta, A.J.; Garssen, J.; Willemsen, L.E.M.; Knippels, L.M.J. Cow milk allergy symptoms are reduced in mice fed dietary synbiotics during oral sensitization with whey. $J$. Nutr. 2009, 139, 1398-1403. [CrossRef]

27. De Kivit, S.; Saeland, E.; Kraneveld, A.D.; Van De Kant, H.J.G.; Schouten, B.; Van Esch, B.C.A.M.; Knol, J.; Sprikkelman, A.B.; Van Der Aa, L.B.; Knippels, L.M.J.; et al. Galectin-9 induced by dietary synbiotics is involved in suppression of allergic symptoms in mice and humans. Allergy Eur. J. Allergy Clin. Immunol. 2012, 67, 343-352. [CrossRef] [PubMed]

28. Hayen, S.M.; Otten, H.G.; Overbeek, S.A.; Knulst, A.C.; Garssen, J.; Willemsen, L.E.M. Exposure of intestinal epithelial cells to short- and long-chain fructo-oligosaccharides and $\mathrm{CpG}$ oligodeoxynucleotides enhances peanut-specific T Helper 1 polarization. Front. Immunol. 2018, 9, 1-13. [CrossRef] [PubMed]

29. van't Land, B.; Schijf, M.; van Esch, B.C.A.M.; van Bergenhenegouwen, J.; Bastiaans, J.; Schouten, B.; Boon, L.; Garssen, J. Regulatory T-cells have a prominent role in the immune modulated vaccine response by specific oligosaccharides. Vaccine 2010, 28, 5711-5717. [CrossRef]

30. Lutz, M.B.; Kukutsch, N.; Ogilvie, A.L.J.; Rößner, S.; Koch, F.; Romani, N.; Schuler, G. An advanced culture method for generating large quantities of highly pure dendritic cells from mouse bone marrow. J. Immunol. Methods 1999, 223, 77-92. [CrossRef]

31. Smit, J.; Zeeuw-Brouwer, M. lène de; van Roest, M.; de Jong, G.; van Bilsen, J. Evaluation of the sensitizing potential of food proteins using two mouse models. Toxicol. Lett. 2016, 262, 62-69. [CrossRef] [PubMed]

32. García-Vallejo, J.J.; Van Het Hof, B.; Robben, J.; Van Wijk, J.A.E.; Van Die, I.; Joziasse, D.H.; Van Dijk, W. Approach for defining endogenous reference genes in gene expression experiments. Anal. Biochem. 2004, 329, 293-299. [CrossRef]

33. Jijon, H.; Backer, J.; Diaz, H.; Yeung, H.; Thiel, D.; McKaigney, C.; De Simone, C.; Madsen, K. DNA from Probiotic Bacteria Modulates Murine and Human Epithelial and Immune Function. Gastroenterology 2004, 126, 1358-1373. [CrossRef] [PubMed]

34. Dwinell, M.B.; Lügering, N.; Eckmann, L.; Kagnoff, M.F. Regulated production of interferon-inducible T-cell chemoattractants by human intestinal epithelial cells. Gastroenterology 2001, 120, 49-59. [CrossRef] [PubMed]

35. de Kivit, S.; van Hoffen, E.; Korthagen, N.; Garssen, J.; Willemsen, L.E.M. Apical TLR ligation of intestinal epithelial cells drives a Th1-polarized regulatory or inflammatory type effector response in vitro. Immunobiology 2011, 216, 518-527. [CrossRef] [PubMed]

36. Thiemann, S.; Baum, L.G. Galectins and Immune Responses-Just How Do They Do Those Things They Do? Annu. Rev. Immunol. 2016, 34, 243-264. [CrossRef] 
37. Cerliani, J.P.; Stowell, S.R.; Mascanfroni, I.D.; Arthur, C.M.; Cummings, R.D.; Rabinovich, G.A. Expanding the universe of cytokines and pattern recognition receptors: Galectins and glycans in innate immunity. J. Clin. Immunol. 2011, 31, 10-21. [CrossRef]

38. Cao, Z.Q.; Guo, X.L. The role of galectin-4 in physiology and diseases. Protein Cell 2016, 7, 314-324. [CrossRef]

39. Hokama, A.; Mizoguchi, E.; Sugimoto, K.; Shimomura, Y.; Tanaka, Y.; Yoshida, M.; Rietdijk, S.T.; De Jong, Y.P.; Snapper, S.B.; Terhorst, C.; et al. Induced reactivity of intestinal CD4+ T cells with an epithelial cell lectin, galectin-4, contributes to exacerbation of intestinal inflammation. Immunity 2004, 20, 681-693. [CrossRef]

40. Paclik, D.; Danese, S.; Berndt, U.; Wiedenmann, B.; Dignass, A.; Sturm, A. Galectin-4 controls intestinal inflammation by selective regulation of peripheral and mucosal $\mathrm{T}$ cell apoptosis and cell cycle. PLoS ONE 2008, 3, e2629. [CrossRef]

41. Tsai, H.F.; Wu, C.S.; Chen, Y.L.; Liao, H.J.; Chyuan, I.T.; Hsu, P.N. Galectin-3 suppresses mucosal inflammation and reduces disease severity in experimental colitis. J. Mol. Med. 2016, 94, 545-556. [CrossRef]

42. Lv, K.; Zhang, Y.; Zhang, M.; Zhong, M.; Suo, Q. Galectin-9 promotes TGF- $\beta 1$-dependent induction of regulatory T cells via the TGF- $\beta$ /Smad signaling pathway. Mol. Med. Rep. 2013, 7, 205-210. [CrossRef]

43. Seki, M.; Oomizu, S.; Sakata, K.M.; Sakata, A.; Arikawa, T.; Watanabe, K.; Ito, K.; Takeshita, K.; Niki, T.; Saita, N.; et al. Galectin-9 suppresses the generation of Th17, promotes the induction of regulatory $\mathrm{T}$ cells, and regulates experimental autoimmune arthritis. Clin. Immunol. 2008, 127, 78-88. [CrossRef] [PubMed]

44. Lin, Y.; Slight, S.R.; Khader, S.A. Th17 cytokines and vaccine-induced immunity. Semin. Immunopathol. 2010, 32, 79-90. [CrossRef] [PubMed]

45. Khader, S.A.; Gaffen, S.L.; Kolls, J.K. Th17 cells at the crossroads of innate and adaptive immunity against infectious diseases at the mucosa. Mucosal Immunol. 2009, 2, 403-411. [CrossRef]

46. Ivanov, I.I.; McKenzie, B.S.; Zhou, L.; Tadokoro, C.E.; Lepelley, A.; Lafaille, J.J.; Cua, D.J.; Littman, D.R. The Orphan Nuclear Receptor ROR $\gamma \mathrm{t}$ Directs the Differentiation Program of Proinflammatory IL-17+ T Helper Cells. Cell 2006, 126, 1121-1133. [CrossRef]

47. Veldhoen, M.; Hocking, R.J.; Atkins, C.J.; Locksley, R.M.; Stockinger, B. TGF $\beta$ in the context of an inflammatory cytokine milieu supports de novo differentiation of IL-17-producing T cells. Immunity 2006, 24, 179-189. [CrossRef] [PubMed]

48. Bettelli, E.; Carrier, Y.; Gao, W.; Korn, T.; Strom, T.B.; Oukka, M.; Weiner, H.L.; Kuchroo, V.K. Reciprocal developmental pathways for the generation of pathogenic effector TH17 and regulatory T cells. Nature 2006, 441, 235-238. [CrossRef]

49. Gruson, D.; Ko, G. Galectins testing: New promises for the diagnosis and risk stratification of chronic diseases? Clin. Biochem. 2012, 45, 719-726. [CrossRef]

50. Katoh, S.; Ikeda, M.; Shimizu, H.; Mouri, K.; Obase, Y.; Kobashi, Y.; Fukushima, K.; Hirashima, M.; Oka, M. Increased levels of plasma galectin-9 in patients with influenza virus infection. Tohoku J. Exp. Med. 2014, 232, 263-267. [CrossRef]

51. Wang, W.H.; Lin, C.Y.; Chang, M.R.; Urbina, A.N.; Assavalapsakul, W.; Thitithanyanont, A.; Chen, Y.H.; Liu, F.T.; Wang, S.F. The role of galectins in virus infection-A systemic literature review. J. Microbiol. Immunol. Infect. 2019, 53, 925-935. [CrossRef] [PubMed]

52. Machala, E.A.; McSharry, B.P.; Rouse, B.T.; Abendroth, A.; Slobedman, B. Gal power: The diverse roles of galectins in regulating viral infections. J. Gen. Virol. 2019, 100, 333-349. [CrossRef] [PubMed] 